\title{
PREVALENCE AND ANTIMICROBIAL SENSITIVITY PATTERN OF PSEUDOMONAS AERUGINOSA FROM CHRONIC SUPPURATIVE OTITIS MEDIA (CSOM) CASES IN A TERTIARY CARE HOSPITAL OF BIHAR
}

\author{
Kumar Ajay'1, Kumari Namrata2, Kumar Shailesh ${ }^{3}$, Kumar Rakesh $^{4}$, Xess Anima ${ }^{5}$, Shahi S. $K^{6}$ \\ ${ }^{1}$ Senior Resident, Department of Microbiology, Indira Gandhi Institute of Medical Sciences (IGIMS), Patna. \\ ${ }^{2}$ Additional Professor, Department of Microbiology, Indira Gandhi Institute of Medical Sciences (IGIMS), Patna. \\ ${ }^{3}$ Additional Professor, Department of Microbiology, Indira Gandhi Institute of Medical Sciences (IGIMS), Patna. \\ ${ }^{4}$ Assistant Professor, Department of Microbiology, Indira Gandhi Institute of Medical Sciences (IGIMS), Patna. \\ 5 Professor, Department of Microbiology, Indira Gandhi Institute of Medical Sciences (IGIMS), Patna. \\ ${ }^{6}$ Professor, Department of Microbiology, Indira Gandhi Institute of Medical Sciences (IGIMS), Patna.
}

ABSTRACT
BACKGROUND
Among the bacteria causing CSOM, Pseudomonas aeruginosa has been particularly blamed for the deep-seated and progressive
destruction of middle ear and mastoid structures through its toxins and enzymes.
Objective- To study the prevalence and antimicrobial sensitivity pattern of P. aeruginosa in CSOM cases.

\section{MATERIALS AND METHODS}

This study was conducted over a time period of one and a half years. Pseudomonas aeruginosa isolates from ear discharge specimens of clinically diagnosed cases of CSOM were identified and confirmed by standard methods. Antimicrobial sensitivity testing of the isolates was done by Kirby-Bauer disc diffusion method according to Clinical and Laboratory Standards Institute (CLSI) guidelines.

\section{RESULTS}

All the $42(100 \%)$ isolates were sensitive to fluoroquinolone group of antibiotics whereas cephalosporin was the second most effective group, which showed 97\% sensitivity. It was followed by Aminoglycosides (60\%), Ampicillin (23\%), Macrolides (22\%) and Amoxicillin/clavulanic acid (15\%).

\section{CONCLUSION}

Overall the most sensitive antibiotic groups were fluoroquinolones and cephalosporins and least effective were penicillins and macrolides. Antimicrobial stewardship should be practised to prevent MDR cases. The infection control measure should be followed properly.

\section{KEYWORDS}

Pseudomonas Aeruginosa, Antibiotic Sensitivity Pattern, CSOM.

HOW TO CITE THIS ARTICLE: Ajay K, Namrata K, Shailesh K, et al. Prevalence and antimicrobial sensitivity pattern of Pseudomonas aeruginosa from chronic suppurative otitis media (CSOM) cases in a tertiary care hospital of Bihar. J. Evolution Med. Dent. Sci. 2017;6(70):5000-5003, DOI: 10.14260/Jemds/2017/1086

\section{BACKGROUND}

Chronic suppurative otitis media (CSOM) is a source of tremendous health predicament since time immemorial and till date it produces immense intricacy both for patients and medical practitioners in general and an otologist in particular. It is a long-standing inflammation of the mucoperiosteum of the middle ear cleft leading to offensive ear discharge and hearing impairment that may have a serious long-term effect on language, auditory, and cognitive development and educational progress. It may be indolent for long time or endanger the life of the patient depending upon the type of pathological process, virulence of organism and the inner build of the individuals.[1]

Financial or Other, Competing Interest: None.

Submission 26-07-2017, Peer Review 20-08-2017,

Acceptance 26-08-2017, Published 31-08-2017.

Corresponding Author:

Dr. Ajay Kumar,

Senior Resident,

Department of Microbiology,

Indira Gandhi Institute of Medical Sciences,

IGIMS, Patna-14.

E-mail:dr.ajay876@gmail.com

DOI: $10.14260 /$ jemds/2017/1086
In CSOM, bacteria can reach the middle ear from the nasopharynx through the Eustachian tube or from the External Auditory Canal (EAC) via a perforated tympanic membrane. Various studies have shown that both Grampositive and Gram-negative organisms are responsible for infection of middle ear, Gram-negative ones outnumbering the Gram-positive. The incidence of single to mixed infection is in the ratio of $4.7: 1$.[2] The most common organisms associated with CSOM are Staphylococcus aureus and Pseudomonas spp. Others include Proteus, E. coli, Klebsiella, Enterobacter, non-fermenting Gram-negative bacteria and beta haemolytic Streptococcus. It is revealed that there is no significant difference in bacterial finding in children and adult.[2]

The role of anaerobes in CSOM is often questioned. They are mostly detected in cases with extensive cholesteatoma or granulation tissue. Fungal infection of the middle ear and meatus are common as fungi thrive well in moist pus. The most commonly seen fungi are Candida and Aspergillus. Development of otalgia, itching and presence of hyphae indicate fungal involvement.[3].The basic principles the medical management of CSOM are aural toilet and the installation of a topical antimicrobial agent. While eradicating a specific organism from a chronically discharging ear will 
reduce the sensitivity of symptoms, it will in case of safe perforation render the ear quiescent. Streptococci respond to oral penicillin, while Haemophilus influenza responds rapidly to oral Amoxicillin or Trimethoprim. Oral Erythromycin or Flucloxacillin may eliminate Staphylococcus aureus. Beta lactamase producing organisms have been identified in $63 \%$ of 175 positive cultures from chronic ears, many of which have been previously treated with antibiotics from the penicillin group. The ability to produce beta lactamase renders them resistant to the semi synthetic penicillin. Proteus, Klebsiella and E. coli are sensitive to oral antibiotics, but fall in to this group. Fourth generation Cephalosporins and Fluoroquinolones, particularly Ciprofloxacin, have given us oral anti-pseudomonals for the first time. They are immensely useful; however, resistant strains are already emerging. Topical antibiotics reach organisms in debris and in mucus more quickly and in greater concentration than oral antibiotics. [4]

\section{MATERIALS AND METHODS}

The study was conducted on 150 patients in the Department of Microbiology, over a period of 18 months from March 2013 to August 2014. The patients attending the ENT Department with more than 3 months history of ear discharge and central perforation, and clinically diagnosed as tubotympanic type of CSOM were included in this study. Each of these patients was subjected to complete history pertaining to name, age, sex, occupation, socioeconomic status, rural and urban distribution, laterality, symptoms like ear discharge, hearing loss, tinnitus, vertigo, itching, otalgia, character of discharge and duration of discharge. Thorough ENT examination was done for each case by otoscopy and PTA (Pure tone audiometry). Radiological and microbiological investigations were also done.

\section{Inclusion Criteria}

Patients diagnosed with active tubotympanic type of chronic suppurative otitis media of more than 6 years of age.

\section{Exclusion Criteria}

- Inactive stage of tubotympanic type of CSOM.

- Atticoantral type of CSOM.

- Otitis externa.

- Current antibiotic use or use in preceding five days (topical and systemic).

- Malignancy of middle ear treatment.

- Previous history of surgery.

Two sterile cotton swabs were used to collect ear discharge from CSOM patients. Only those cases were selected who had not taken any treatment either systemic or local in the form of ear drops for the last seven days. One swab was used for performing Gram stain and $\mathrm{KOH}$ preparation and second one for culture. Culture was done on nutrient agar, blood agar, MacConkey agar and SDA. The organisms were identified by culture characters, morphology, and pigment production, beta-haemolysis on blood agar, motility and conventional biochemical tests. Antimicrobial susceptibility test for all isolates was performed on MuellerHinton agar plate using Kirby-Bauer disc diffusion methods. Antibiotic discs were procured from HiMedia Labs Mumbai Result were interpreted using Clinical Laboratory Standards Institute (CLSI) guidelines.

\section{Statistical Analysis}

The data collection was entered in the Microsoft Excel computer program using SPSS version 16.0, and checked for any discrepancy. The result was presented in proportion/percentages.

\section{Ethical Consideration}

Ethical clearance was taken from Institutional Ethical Committee.

\section{RESULTS}

A total of 152 swabs were collected from 150 cases and sent for culture sensitivity. Out of those, 30 (19.7\%) were sterile while 122 swabs yielded growth of organisms. Gram staining of the 152 swabs showed predominance of Gram-negative organisms with Gram-negative bacilli in $41.4 \%$ ears. Out of 152 swabs, 4 (3.3\%) yielded polymicrobial organisms, while 115 (96.6\%) yielded monomicrobial flora. In three swabs, fungal growth was seen. Among the monomicrobial isolates, Pseudomonas aeruginosa was the commonest offender seen in $42(36.5 \%)$ swabs, followed by Staphylococcus aureus in 34 (29.5\%) ears. Polymicrobial isolation was associated with Pseudomonas spp. and Staphylococcus aureus. Age range was from 6 to 70 years, with a mean age of 27.17 years with S.D. \pm 16.8. Maximum numbers of cases were found to be in the second or third decade with 35 (23.3\%) cases each in 11-20 and 21-30 years age group. There was a male preponderance with a male to female ratio of 1.3:1. Maximum number of cases were from lower middle socioeconomic class (36.6\%). Most of the cases (53.3\%) presented with left ear involvement. All of the Pseudomonal species were sensitive to Fluoroquinolones group of antibiotics. Cephalosporins were the second most effective group, showing $97 \%$ sensitivity followed by Aminoglycosides (60\%), Ampicillin (23\%), Macrolides (22\%) and Amoxicillin/clavulanic acid (15\%). Most sensitive antibiotic groups were Fluoroquinolones and Cephalosporins and least effective were Penicillins and Macrolides.

\begin{tabular}{|c|c|c|c|}
\hline Gram Stain & Isolate & Number & Percentage \\
\hline \multirow{4}{*}{$\begin{array}{c}\text { Gram } \\
\text { negative } \\
(n=63)\end{array}$} & Pseudomonas spp. & 42 & $36.5 \%$ \\
\hline & Proteus spp. & 13 & $11.3 \%$ \\
\hline & E. coli & 4 & $3.4 \%$ \\
\hline & Citrobacter & 4 & $3.4 \%$ \\
\hline \multirow{2}{*}{$\begin{array}{c}\text { Gram } \\
\text { positive } \\
(\mathrm{n}=52)\end{array}$} & $\begin{array}{l}\text { Staphylococcus } \\
\text { aureus }\end{array}$ & 34 & $29.5 \%$ \\
\hline & $\begin{array}{c}\text { Coagulase- } \\
\text { negative Staph }\end{array}$ & 18 & $15.6 \%$ \\
\hline
\end{tabular}

\begin{tabular}{|c|c|c|c|c|}
\hline \multicolumn{5}{|c|}{ Pseudomonas Species } \\
\hline Antibiotic & $\begin{array}{c}\text { Indudharan } \\
\text { et al. }\end{array}$ & $\begin{array}{c}\text { Ayson } \\
\text { et al. }\end{array}$ & $\begin{array}{c}\text { Poorey } \\
\text { \& Aiyer }\end{array}$ & $\begin{array}{c}\text { Present } \\
\text { Study }\end{array}$ \\
\hline Ampicillin & $2.4 \%$ & $35.7 \%$ & $66.6 \%$ & $23 \%$ \\
\hline $\begin{array}{c}\text { Amoxicillin/ } \\
\text { clavulanic acid }\end{array}$ & - & - & - & $15 \%$ \\
\hline Macrolides & - & $22.2 \%$ & - & $22 \%$ \\
\hline Aminoglycosides & - & $83.3 \%$ & $75.4 \%$ & $60 \%$ \\
\hline Cephalosporins & $100 \%$ & - & $76.4 \%$ & $97 \%$ \\
\hline $\begin{array}{c}\text { Fluoro- } \\
\text { quinolones }\end{array}$ & $98.9 \%$ & $85.7 \%$ & $81.3 \%$ & $100 \%$ \\
\hline \multicolumn{7}{|c|}{ Table 2. Antibiogram of Pseudomonas spp. } \\
\hline
\end{tabular}




\section{DISCUSSION}

In CSOM, bacteria can reach the middle ear from the nasopharynx through the Eustachian tube or from the external auditory canal (EAC) via a perforated tympanic membrane. Untreated cases of CSOM can result in broad range of complications.

In the present study, age of the patient ranged from 6 to 70 years. The mean age was 27.17 years with standard deviation of \pm 16.8. The commonest age group of presentation was $11-20$ and 21-30 years, consisting 35 $(23.3 \%)$ cases in each category. These findings were consistent with the findings of Shreshtha \& Sinha ${ }^{5}$ and Singh \& Safaya ${ }^{6}$. However, a much earlier presentation was reported by Rupa $\mathrm{V}$ et $\mathrm{al}^{7}$ and Vikram BK et al. ${ }^{8}$ They concluded that the disease was more frequently seen in children because of immature immunity and supplementary upper respiratory tract contagion. The basis for delayed presentation in our study may be due to recklessness of the patients to seek consideration about their health. They only think about the necessity of the medical contemplation once they accomplish the age of nuptials or employment.

The present study showed that CSOM was diagnosed in males (58\%) as compared to females $(42 \%)$. The ratio of male to female patients was 1.3:1. Analogous conclusion has been made by Chandra \& Mishra ${ }^{9}$, Mukherjee $\mathrm{P}$ et al and Hossain MM et al. ${ }^{10}$ They concluded that the predominant burden of the disease in males was due to their outdoor working habits exposing them for contamination and contagion. Wang HM et al ${ }^{11}$ De Vos $\mathrm{C}$ et $\mathrm{al}^{12}$ and reported a female preponderance in their study with the prevalence of $57.9 \%$ and $57 \%$ respectively. They elucidated that the females in hilly locale accomplish the majority of the outdoor exertion, and hence, are more exposed to the climate and atmospheric changes. The indiscriminate attitude of the society towards females prevents them from proper medical education and amenities making them vulnerable for recurrent middle ear infection.

In the present study, unilateral aural involvement was seen in $98.6 \%$ cases, of which, left and right ear were involved in $53.3 \%$ and $45.3 \%$ respectively. Bilateral ear involvement was only seen in $1.3 \%$ patients.

Comparable results were obtained in the study of Kamal $\mathrm{N}$ et $\mathrm{al}^{13}$ and Olusesi $\mathrm{AD}^{14}$ with similar predominance of left ear. In contrast, Gulati SP et al observed right side involvement in $51.5 \%$ cases. Majority of the studies concluded that TT of CSOM predominantly involved right side, as the deviated nasal septum is more common on right side and moreover, skull is tilted to $15^{\circ}$ on the right side. Our findings are not in accordance with these studies. The scrutiny of the cause of left side predominance needs further evaluation which was beyond the scope of present study.

In the aerobic culture, the commonest organism isolated was Pseudomonas species in $46(38.6 \%)$ ears. Bairy I et al also found Pseudomonas aeruginosa (33.9\%) as the commonest organism. Similarly, Poorey \& lyer $^{15}$ isolated Pseudomonas in 35.2\% ears. Pseudomonas was also isolated as the predominant organism by Maji PK et al ${ }^{16}(63.8 \%)$, Kumar S et $\mathrm{al}^{17}$ (45.9\%) and Indudharan $\mathrm{R}$ et al ${ }^{18}$ (27.2\%).

The occurrence of Pseudomonas aeruginosa as the prime offender can be attributed to various factors. Pseudomonas, survives competition with other pathogens due to its minimal nutritional requirement and its armamentarium of antibacterial products, pyocyanin and bacteriocin. Vartiainen \& Vartiainen ${ }^{19}$ postulated that Pseudomonas has the ability to carve out a niche for itself in local infection through the necrotising activities of its extracellular enzymes. The physical characteristics of the niche, damaged epithelium, interrupted circulation and devitalised tissue protects the organism from normal host defence mechanisms and antibiotic agents. In addition, the organism acts as an opportunistic pathogen, flourishes in external auditory canal and may cause suppurative disease in contiguous sites. Staphylococcus aureus 38 (31.9\%) was the second most common pathogen isolated in the present study. Similar number of isolation has been reported by Kukreja SM et al ${ }^{20}$ (33.9\%), Freidmann I21 (32.1\%), Nikakhlagh S et al ${ }^{22}(32.4 \%)$ and Ettehad G et al ${ }^{23}$ (31.1\%). However, Staphylococcus aureus was reported as the commonest pathogen by Pajor A et $\mathrm{al}^{24} \mathrm{Ayson} \mathrm{AN}$ et $\mathrm{al},{ }^{25}$ and Gupta $\mathrm{V}$ et $\mathrm{al}^{26}$ in their respective studies. They explained that the high incidence of Staphylococcus aureus in CSOM could be attributed to its ubiquitous nature and high carriage in the external auditory canal and upper respiratory tract.

Microbial sensitivity of Pseudomonas revealed that all the isolates were sensitive to Fluoroquinolones, while, 97\% were sensitive to the cephalosporin group and $60 \%$ to aminoglycosides. Only $23 \%, 22 \%$ and $15 \%$ were sensitive to Ampicillin, Macrolides and Amoxicillin- clavulanic acid respectively. Similar data were obtained by Akhtar $\mathrm{N}$ et al ${ }^{27}$ in which most of the Pseudomonal isolates showed more than 90\% sensitivity to Fluoroquinolones, followed by Cephalosporin and Aminoglycosides. Majority were found to be resistant to Penicillins and Macrolides. Indudharan $\mathrm{R}$ et al also obtained identical results in their study. They observed that the sensitivity was $100 \%$ to Cephalosporin, $98.9 \%$ to Fluoroquinolones while the organism was almost resistant to Penicillin (97.6\%). The result of present study was in accordance to Loy $\mathrm{AH}$ et al. $^{28}$ They observed that Pseudomonas aeruginosa showed $90 \%$ sensitivity to Cephalosporins, Fluoroquinolones, anti-Pseudomonal Penicillins and Aminoglycosides. Ettehad G et al also found high sensitivity rates for Fluoroquinolones (85.7\%) and nearly $100 \%$ resistance to Ampicillin. Bairy I et al ${ }^{29}$ also concluded that Ampicillin (1.5\%) and Amoxicillin/clavulanic acid $(6.3 \%)$ were the least effective antibiotics. Data from Ayson AN et al study showed $64.3 \%$ resistance to Penicillins while Fluoroquinolones were active against $85.7 \%$ isolates followed by Amikacin (83.3\%).

However, some results have shown a much lower sensitivity pattern for Fluoroquinolones. Kumar $S$ et al 30 reported only $63.2 \%$ sensitivity for Ofloxacin and $59.6 \%$ sensitivity for Ciprofloxacin. Similarly, Maji PK et al showed $46.6 \%$ sensitivity rate of Ciprofloxacin. The decreased sensitivity of Pseudomonas to the quinolone family, to which it was highly sensitive until recently, is indicative of the rapid appearance of antibiotic-resistant strains of Pseudomonas which is a matter of great concern.

\section{CONCLUSION}

The indiscriminate and haphazard use of antibiotics and poor followup of these patients has resulted in the emergence of multiple resistant strains of bacteria and the persistence of low-grade infection. Changes in the microbiological flora following the advent of sophisticated synthetic antibiotics 
increase the relevance of reappraisal of the modern-day flora in CSOM. Knowledge of the prevailing flora and their susceptibility to antimicrobials will guide the clinician in prescribing an empirical regimen so that a better and more specific management can be provided to the patients. Hence, this study is relevant in the present scenario.

\section{REFERENCES}

[1] Healy GB, Rosbe KW. Otitis media and middle ear effusion. In: Snow, Ballenger JJ, (eds). Ballengers otorhinolaryngology head neck surgery. $16^{\text {th }}$ edn. BC Decker Inc 2003:249-60.

[2] Varshney S, Gupta P. Bacteriological study of chronic suppurative otitis media. Indian J Otol 1999;5(2):8791.

[3] Ibekwe A0, al Shareef Z, Benayam A. Anaerobes and fungi in chronic suppurative otitis media. Ann Otol Rhino Laryngol 1997;106(8):649-52.

[4] Holmberg SD, Solomon SL, Blake PA. Health and economic impacts of antimicrobial resistance. Rev Infect Dis 1987;9(6):1065-78.

[5] Shreshtha S, Sinha BK. National committee for clinical laboratory standards. Performance standards for antimicrobial susceptibility testing. USA Wayne, PA: NCCLS. Hearing results after myringoplasty 2001:M100-S1.

[6] Singh RK, Safaya A. Middle ear hearing restoration using autologous cartilage graft in canal wall down mastoidectomy. Ind J Otol 2005;11:10-4.

[7] Rupa V, Jacob A, Joseph A. Chronic suppurative otitis media: prevalence and practices among rural South Indian children. Int J Pediatr Otorhinolaryngol 1999;48(3):217-21.

[8] Vikram BK, Khaja N, Udayashankar SG, et al. Clinicoepidemiological study of complicated and uncomplicated chronic suppurative otitis media. J Laryngol Otol 2008;122(5):442-6.

[9] Chandra R, Mishra RN. Some observations on the total and subtotal perforations of the tympanic membranes. Ind J Otolaryngol 1964;16(1):1-20.

[10] Mukherjee P, Saunders N, Liu R, et al. Long-term outcome of modified radical mastoidectomy. J Laryngol Otol 2004;118(8):612-6.

[11] Wang HM, Lin JC, Lee KW, et al. Analysis of mastoid findings at surgery to treat middle ear cholesteatoma. Arch otolaryngol Head Neck Surg 2006;132(12):130710.

[12] De Vos C, Gersdorff M, Gerard JM. Prognostic factors in ossiculoplasty. Otol Neurotol 2007;28(1):61-7.

[13] Kamal N, Joarder AH, Chowdhury AA, et al. Prevalence of chronic suppurative otitis media among the children living in two selected slums of Dhaka city. Bangladesh Med Res Counc Bull 2004;30(3):95-104.

[14] Olusesi AD. Otitis media as a cause of significant hearing loss among Nigerians. Int J Pediatr Otorhinolaryngol 2008;72(6):787-92.
[15] Poorey VK, Lyer A. Study of bacterial flora in CSOM and its clinical significance. Ind J otolaryngol Head Neck Surg 2002;54(2):91-5.

[16] Maji PK, Chatterjee TK, Chatterjee S, et al. The investigation of bacteriology of chronic suppurative otitis media in patients attending a tertiary care hospital with special emphasis on seasonal variation. Ind J Otolaryngol Head Neck Surg 2007;59(2):128-31.

[17] Kumar S, Sharma R, Saxena AK, et al. A study of bacterial flora and sensitivity to antibiotics in cases of CSOM TTD in western UP. Ind J Otol 2008;14:20-4.

[18] Indudharan R, Haq JA, Aiyar S. Antibiotics in chronic suppurative otitis media: a bacteriologic study. Ann Otol Rhinol Laryngol 1999;108(5):440-5.

[19] Vartiainen E, Vartianen J. Effect of aerobic bacteriology on the clinical presentation and treatment results of chronic suppurative otitis media. J of Laryngol Otol 1996;110(4):315-8.

[20] Kukreja SM, Kohli GS, Mohan C, et al. Microbiological study in chronic suppurative otitis media. Ind Med Gazette 1979;3:95-8.

[21] Freidmann I. Bacteriological studies in otitis. J Laryngol Otol 1952;66(4):175-80.

[22] Nikakhlagh S, Khosravi AD, Fazlipour A, et al. Microbiologic findings in patients with chronic suppurative otitis media. J Med Sci 2008;8(5):503-6.

[23] Ettehad G, Refani S, Nemmati A, et al. Microbial and antimicrobial susceptibility patterns from patients with chronic otitis media in Ardebil. Int J Tropi Med 2006;1(2):62-5.

[24] Pajor A, Durko M, Jankowski A, et al. Bacteriological evaluation in chronic otitis media. Otolaryngol Pol 2006;60(5):757-63.

[25] Ayson AN, Lopez JEG, Llanes EGD. Chronic suppurative otitis media: bacteriology and drug sensitivity patterns at the Quirino memorial medical centre (2004-05): a preliminary study. Phillip J Otolaryngol Head Neck Surg 2006;21(1,2):20-3.

[26] Gupta V, Gupta A, Sivarajan K. Chronic suppurative otitis media: an aerobic microbiological study. Ind J Otol 1998;4(2):79-82.

[27] Akhtar N, Muhammad A, Khan AA, et al. Bacteriology of chronic suppurative otitis media and antibiotic sensitivity pattern of the bacteria isolated. Prof Med J 2004;11(1):1-5.

[28] Loy AH, Tan AL, Lu PK. Microbiology of chronic suppurative otitis media in Singapore. Singapore Med J 2002;43(6):296-9.

[29] Bairy I, Pradhan D, Yenigalla BM. Microbiology of chronic suppurative otitis media. lnt J Otol 2007;13:21-4.

[30] Kumar S, Sharma R, Saxena AK, et al. A study of bacterial flora and sensitivity to antibiotics in cases of CSOM TTD in western UP. Ind J Otol 2016;14:20-4. 